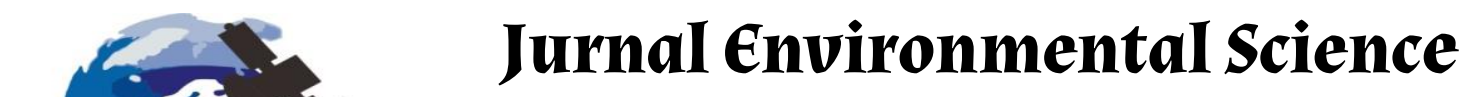

Volume 1 Nomor 2 April 2019

p-ISSN : 2654-4490 dan e-ISSN : 2654-9085

JURNALENVIRONMENTAL SCIENCE

Homepage at : ojs.unm.ac.id/JES

E-mail:jes@unm.ac.id

\title{
ZONASI LAHAN BERPOTENSI UNTUK BUDIDAYA TANAMAN TEH (CAMELLIA SINENSIS L. KUNTZE) DI SUB DAS PASUI HULU DAS SADDANG
}

\author{
Muh. Faisal Juanda \\ Jurusan Geografi, Fakultas Matematika dan Ilmu Pengetahuan Alam, \\ Universitas Negeri Makassar, 2019, Indonesia.
}

\begin{abstract}
This research aims to know actual land suitability potential for Tea (Camellia Sinensis L. Kuntze) in Pasui Sub watershed, Saddang upstream watershed. The method of this research is random stratified sampling on 58 land units with take 9 samples. From the research summarizes suitability class are suit enough (S2) spread on 6 land units width it is 70,91 ha. Marginal suit (S3) spread on 47 land units width it is 13376,14 ha and not suit (N) spreads on 5 land units width it is 61,85 ha. Conclusions from above that potential to grow tea crop in Pasui sub watershed, Saddang upstream watershed are three class of suitability, Suit enough (S2), Marginal Suit (S3), and Not Suit $(N)$. Most Heavy limiting factor are temperature, nutritions retention in case base saturation and erosion hazards in case slopes.
\end{abstract}

Keywords: Land Suitability,Tea (Camellia Sinensis L. Kuntze)

ABSTRAK

Penelitian ini bertujuan untuk mengetahui potensi kesesuaian lahan aktual teh (Camellia Sinensis L. Kuntze) di Sub DAS, DAS Saddang hulu. Metode penelitian ini adalah stratified random sampling pada 58 satuan lahan dengan pengambilan 9 sampel. Dari hasil penelitian dirangkum kelas kesesuaian cukup sesuai (S2) tersebar pada 6 satuan luas lahan yaitu 70,91 ha. Margin suit (S3) yang tersebar di 47 satuan luas lahan adalah 13376,14 ha dan tidak sesuai (N) tersebar di 5 satuan luas lahan yaitu 61,85 ha. Tanaman teh di sub DAS, hulu Saddang hulu adalah tiga kelas kesesuaian, cukup sesuai (S2), Marginal Suit (S3), dan Not Suit (N). Faktor pembatas yang paling berat adalah suhu, retensi nutrisi pada saturasi basa dan bahaya erosi jika terjadi lereng.

Kata kunci: Kesesuaian Lahan, Teh (Camellia Sinensis L. Kuntze) 


\section{PENDAHULUAN}

Teh atau dengan nama latin Camellia Sinensis L. Kuntze merupakan salah satu tanaman industri/perkebunan. Indonesia menduduki peringkat keenam negara pengeksport teh setelah Kenya, Srilangka, Vietnam dan India (Sukmono, 2015). Pada tahun - tahun sebelumnya luas area perkebunan teh di Indonesia mengalamai fluktuasi. Penurunan luas perkebunan terjadi pada tahun 2011(123.938 ha) sampai dengan tahun 2016 (117.268 ha).

Menurut beberapa penelitian sebelumnya pada International Scientific Symposium on Tea \& Human Health tahun 2012 bahwa teh sangat bermanfaat bagi tubuh diantarnya adalah kandungan cathecini pada teh membantu penurunan berat badan, membantu memperbaiki gangguan kognitif ringan, membantu metabolisme tubuh, kandungan polyfenol pada teh hijau dapat memberikan manfaat membangun tulang yang spesifik termasuk memperbaiki pembentukan tulang, menurunkan degradasi tulang, mencegah beberapa jenis kanker dan tumor, serta membantu kesehatan jantung.

Pembudidayaan tanaman teh harus harus melalui beberapa langkah teknis. Pemetaaan dan survey lapang merupakan langkah awal untuk mengetahui letak-letak lahan yang berpotensi sesuai untuk ditanami tanaman teh. Khususnya untuk tanaman teh dibutuhkan banyak data dan informasi dalam menilai lahan yang akan ditanami. Data - Data diperoleh akan menghasilkan informasi kesesuaian lahan aktual suatu lahan. Hal ini dilakukan demi mendapatkan kepuasan hasil budidaya tanaman yang diinginakan.

Satu - satunya perkebunan teh yang ada di provinsi Sulawesi Selatan berada di utara Kota Malino tepatnya kelurahan Patappang, kecamatan Tinggimoncong. Daerah lain di Sulawesi selatan yang cenderung memiliki kemiripan dengan daerah Kabupaten Gowa adalah kabupaten Enrekang baik dari segi topografi, iklim dan tanah. Daerah Kabupaten Enrekang yang berada pada ketinggian diprediksi memiliki potensi untuk budidaya tanaman teh adalah pada hulu DAS Saddang tepatnya di Sub DAS Pasui.

\section{METODE PENELITIAN}

Adapun jenis penelitian yang akan dilakukan adalah kualitatif deskriptif. Menurut Sugiyono (2008) bahwa penelitian kualitatif deskriptif adalah metode penelitian yang berlandaskan pada filsafat postpositivisme yang biasanya digunakan untuk meneliti pada kondisi objektif yang alamiah dimana peneliti berperan sebagai instrumen kunci. Penelitan in bermaksud untuk menzonasi lahan yang memiliki kesesuaian lahan aktual untuk tanaman Teh (Camellia Sinensis L. Kuntze) di Sub DAS Pasui. Metode pengambilan sampel menggunakan stratified random sampling di beberapa unit satuan lahan pada peta hasil tumpang susun (overlay).

Instrument penelitian yang digunakan dalam penelitian ini sebagai berikut:

1) Alat

Adapun alat - alat yang diperlukan diantaranya sebagai berikut

a) Global positioning system (GPS), untuk menentukan posisis di permukaan bumi.

b) Clinometer, untuk pengukuran kelerengan pada lokasi pengambilan sampel.

c) Kompas, untuk mengetahui arah kemiringan lereng.

d) Roll meter, untuk mengetahui kedalaman efektif tanah.

e) Bor tanah, untuk pengambilan sampel tanah.

f) Ring sampel, untuk mengambil tanah tidak teruskik

g) $\mathrm{pH}$ meter digital, untuk mengukur $\mathrm{pH}$ langsung dilapangan

h) Plastik (kantung sampel), sebagai wadah penyimpanan sampel tanah.

i) Alat tulis menulis, untuk mencata hasil pengukuran dan hasil pengamatan.

2) Bahan

Adapun bahan yang diperlukan diantaranya sebagai berikut:

a) Peta Satuan lahan Sub DAS Pasui, hulu DAS Saddang

b) Citra Sub DAS Pasui, hulu DAS Saddang

Teknik Analisis Data

Analisis data yang digunakan dalam penelitian ini yaitu analisis deskriptif dengan tujuan untuk menggambarkan atau mendeskripsikan keadaan lokasi, serta sebaran lahan yang berpotensi memiliki kesesuaian lahan actual untuk potensi budidaya tanaman teh. Adapun teknik yang digunakan dalam analisisnya yaitu teknik pencocokan (Matching) dan kartografi. 


\section{HASIL}

\section{1) Gambaran Umum Lokasi Penelitian}

Lokasi Penelitian berada ini di Sub DAS Pasui, Hulu DAS Saddang. Sub DAS ini secara Astronomis terletak pada $119^{\circ} 51^{\prime} 53.23^{\prime \prime}$ BT - $120^{\circ} 2^{\prime}$ 22,70" BT dan 322' 31,49" LS - 32 29' 23,67" LS. Sungai - sungai Sub DAS Pasui mengaliri dua kecamatan di yaitu kecamatan Baraka dan kecamatan Buntu Batu. Hulu Sub DAS ini berada di desa Latimojong dan hilir berada di desa Tomenawa. Luas Sub DAS Pasui adalah 13508,9 hektar. Titik elevasi tertinggi berada pada $3748 \mathrm{~m}$ diatas permukaan laut, sedangkan titik elevasi terendah berada pada $475 \mathrm{~m}$ diatas permukaan laut.

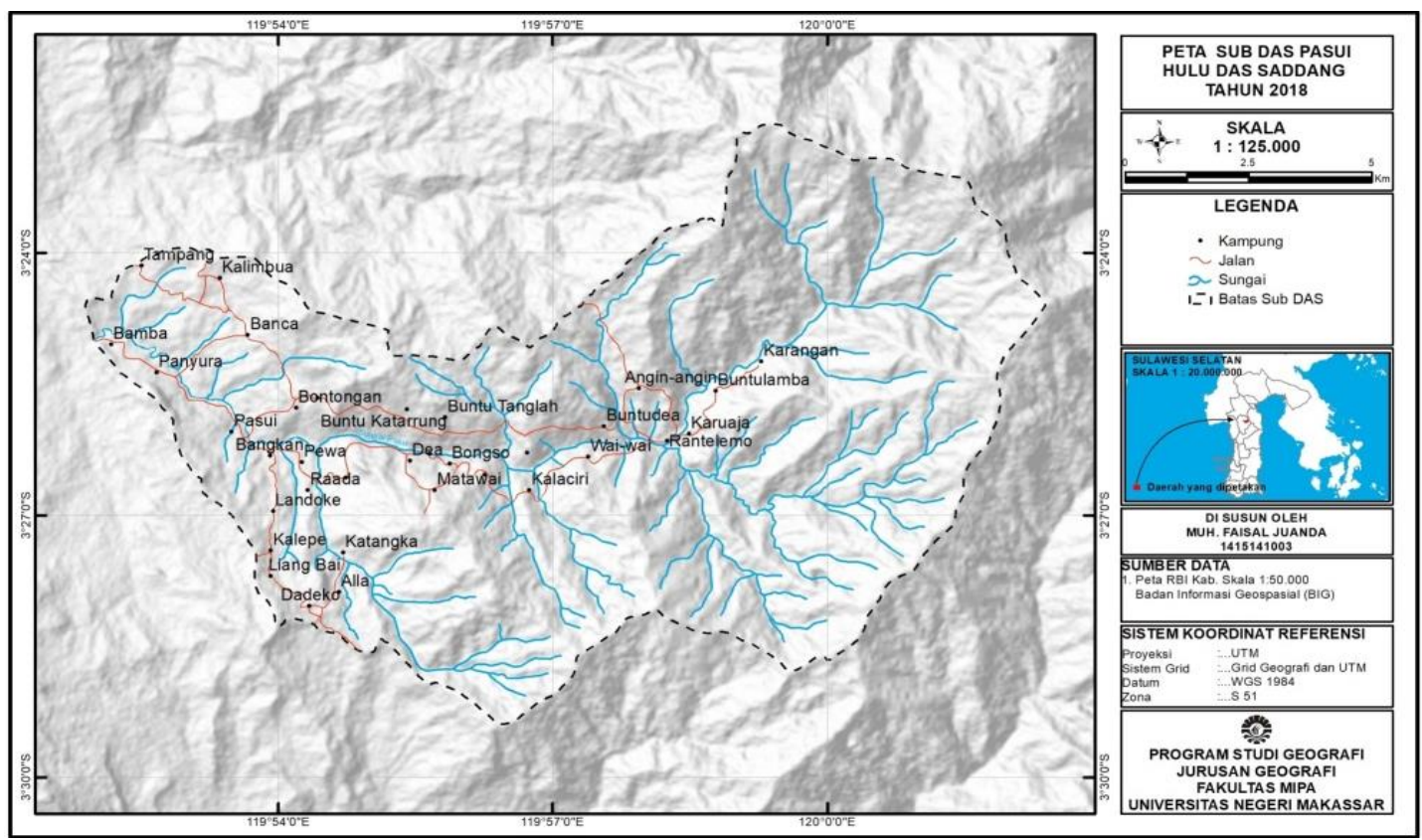

Gambar 1. Peta Sub DAS Pasui, hulu DAS Saddang 


\section{2) Hasil}

Berdasarkan hasil tumpang susun peta kelerengan, bentuklahan, penggunaan lahan dan jenis tanah maka diperoleh peta satuan lahan seperti pada gambar 2

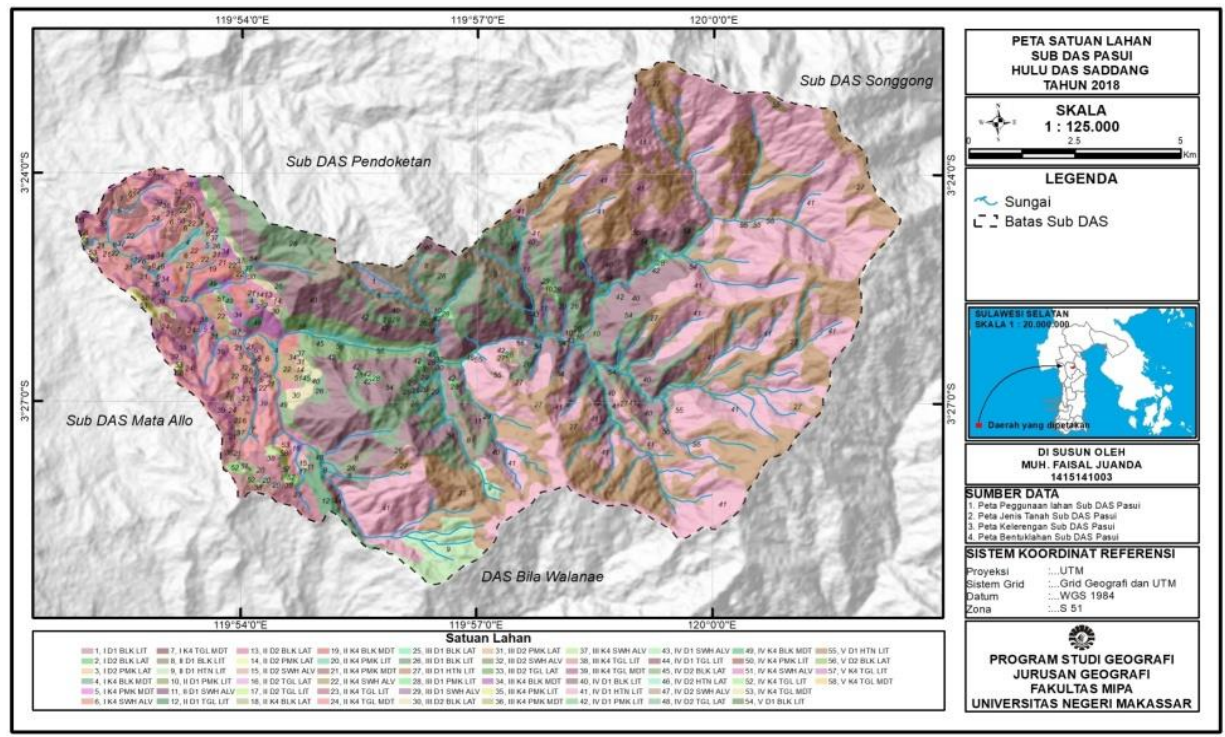

Gambar 2 Peta Satuan lahan sub DAS Pasui

Berdasarkan peta 1.2 tentang peta satuan lahan di sub DAS Pasui dapat diketahui bahwa hasil tumpang susun (overlay) menghasilkan 58 unit satuan lahan. Pada penelitian ini terdapat 9 titik yang digunakan sebagai titik sampel penelitian. Lokasi pengambilan sampel dapat dilihat pada gambar 1.3 berikut

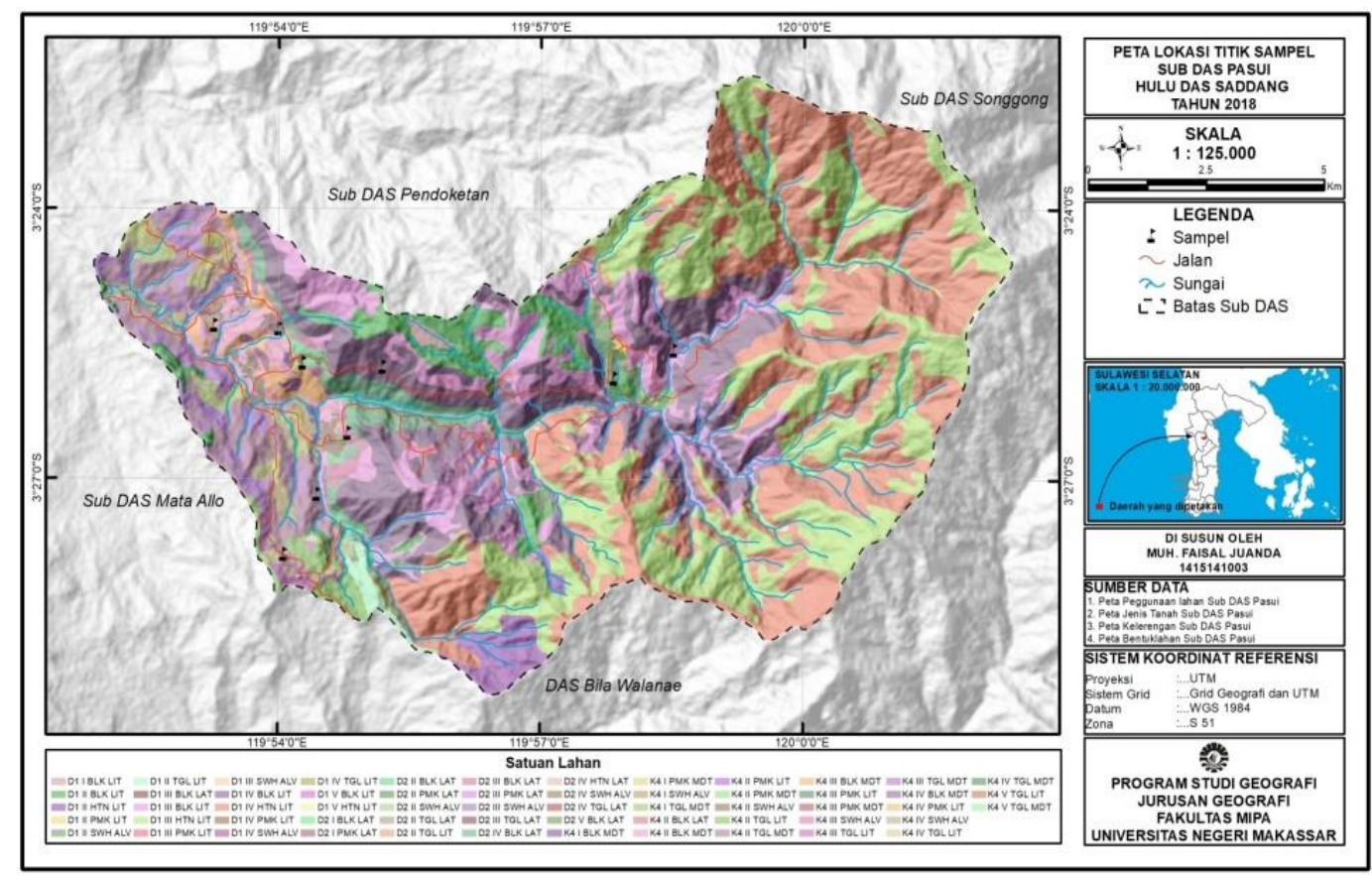

Gambar 3 Peta lokasi titik sampel sub DAS Pasui 


\begin{tabular}{|c|c|c|c|c|c|c|c|c|c|c|c|}
\hline \multirow{2}{*}{ No. } & \multirow{2}{*}{$\begin{array}{l}\text { Sampel } \\
\text { Satuan } \\
\text { lahan }\end{array}$} & \multirow{2}{*}{$\begin{array}{c}\text { Suhu (tc) } \\
\text { Temperatur }\end{array}$} & \multirow{2}{*}{$\begin{array}{c}\begin{array}{c}\text { Ketersediaan } \\
\text { air (wa) }\end{array} \\
\text { Curah hujan }\end{array}$} & \multirow{2}{*}{ Drainase } & \multicolumn{3}{|c|}{ Keadaan perakaran $(\mathrm{rc})$} & \multicolumn{4}{|c|}{ Retensi hara (nr) } \\
\hline & & & & & $\begin{array}{c}\text { Tekstur } \\
\text { tanah }\end{array}$ & $\begin{array}{c}\text { Fraksi } \\
\text { kasar }\end{array}$ & $\begin{array}{c}\text { Kedalaman } \\
\text { efektif } \\
\text { tanah }\end{array}$ & $\begin{array}{c}\text { KTK } \\
\text { liat }\end{array}$ & $\begin{array}{l}\text { Kej. } \\
\text { Basa }\end{array}$ & $\begin{array}{c}\mathbf{p H} \\
\mathbf{H} 2 \mathrm{O} \\
\end{array}$ & $\begin{array}{c}\text { C- } \\
\text { organik }\end{array}$ \\
\hline 1 & $\begin{array}{l}\text { III, D1, } \\
\text { Blk, Lit }\end{array}$ & $18.97 / \mathrm{S} 2$ & $1914,4 / \mathrm{S} 2$ & Baik/S1 & $\begin{array}{c}\text { Agak } \\
\text { halus/S1 }\end{array}$ & $23 / \mathrm{S} 2$ & $110 / \mathrm{s} 1$ & $49,85 / \mathrm{S} 1$ & $22,5 / \mathrm{S} 2$ & $5,75 / \mathrm{S} 2$ & $1,94 / \mathrm{S} 1$ \\
\hline 2 & $\begin{array}{l}\text { IV, D1, } \\
\text { Tgl, Lit }\end{array}$ & $19.34 / \mathrm{S} 1$ & $1914,4 / \mathrm{S} 2$ & Baik/S1 & $\begin{array}{c}\text { Agak } \\
\text { halus/S1 }\end{array}$ & $35 / \mathrm{S} 2$ & $105 / \mathrm{s} 1$ & $77,50 / \mathrm{s} 1$ & $32,5 / \mathrm{S} 2$ & $6,5 / \mathrm{s} 3$ & $2,31 / \mathrm{S} 1$ \\
\hline 3 & $\begin{array}{l}\text { I, K4 } \\
\text {,Swh, Alv }\end{array}$ & $22.42 / \mathrm{S} 2$ & $1914,4 / \mathrm{S} 2$ & Baik/S1 & Halus/S1 & $1 / \mathrm{S} 1$ & $113 / \mathrm{S} 1$ & $58,89 / \mathrm{S} 1$ & $43 / \mathrm{S} 3$ & $6,25 / \mathrm{S} 3$ & $2,15 / \mathrm{S} 1$ \\
\hline 4 & $\begin{array}{l}\text { II, K4, } \\
\text { Tgl, Mdt }\end{array}$ & $21.25 / \mathrm{s} 2$ & $1914,4 / \mathrm{S} 2$ & Baik/S1 & Halus/S1 & $15 / \mathrm{S} 2$ & $118 / \mathrm{S} 1$ & $78,90 / \mathrm{S} 1$ & $49,5 / \mathrm{S} 3$ & $6 / s 3$ & $2,35 / \mathrm{s} 1$ \\
\hline 5 & $\begin{array}{l}\text { V, K4, } \\
\text { Tgl, Mdt }\end{array}$ & $20.65 / \mathrm{s} 1$ & $1914,4 / \mathrm{S} 2$ & Baik/S1 & $\begin{array}{c}\text { Agak } \\
\text { halus/S1 }\end{array}$ & $10 / \mathrm{S} 1$ & $180 / \mathrm{S} 1$ & $52,76 / \mathrm{S} 1$ & $57,5 / \mathrm{S} 3$ & $6 / s 3$ & $1,76 / \mathrm{S} 1$ \\
\hline 6 & $\begin{array}{l}\text { III, D2, } \\
\text { Swh, Alv }\end{array}$ & $21.28 / \mathrm{S} 2$ & $1914,4 / \mathrm{S} 2$ & Baik/S1 & $\begin{array}{c}\text { Agak } \\
\text { halus/S1 }\end{array}$ & $25 / \mathrm{S} 2$ & $110 / \mathrm{s} 1$ & $68,91 / \mathrm{S} 1$ & $47,5 / \mathrm{S} 3$ & $7 / \mathrm{s} 3$ & $1,89 / \mathrm{S} 1$ \\
\hline 7 & $\begin{array}{l}\text { I,D2, Tgl, } \\
\text { Lat }\end{array}$ & $20.73 / \mathrm{s} 2$ & $1914,4 /$ S2 & Baik/S1 & Halus/S1 & $5 / \mathrm{S} 1$ & $178 / \mathrm{S} 1$ & $58,08 / \mathrm{S} 1$ & $26 / \mathrm{S} 3$ & $5,75 / \mathrm{S} 2$ & $2,22 / \mathrm{S} 1$ \\
\hline 8 & $\begin{array}{l}\text { III, D2, } \\
\text { Tgl, Lat }\end{array}$ & $21.07 / \mathrm{S} 2$ & $1914,4 / \mathrm{S} 2$ & Baik/s1 & $\begin{array}{c}\text { Agak } \\
\text { halus/S1 }\end{array}$ & $10 / \mathrm{S} 1$ & $210 / \mathrm{s} 1$ & $46,29 / \mathrm{S} 1$ & $23 / \mathrm{s} 2$ & $5,5 / \mathrm{s} 2$ & $2,16 / \mathrm{S} 1$ \\
\hline 9 & $\begin{array}{l}\text { II, D1, } \\
\text { Blk, Lit }\end{array}$ & $19.21 / \mathrm{S} 1$ & $1914,4 /$ S2 & Baik/S1 & $\begin{array}{c}\text { Agak } \\
\text { halus/S1 }\end{array}$ & $27 / \mathrm{S} 2$ & $150 / \mathrm{S} 1$ & $61,82 / \mathrm{S} 1$ & $30,5 / \mathrm{S} 2$ & $7 / \mathrm{S} 3$ & $1,60 / \mathrm{S} 1$ \\
\hline
\end{tabular}

.Adapun karakteristik lahan pada titik sampel yang diambil disajikan pada tabel 1 berikut.

Tabel 1 Karakteristik Sampel dan kesesuaian lahan aktual

Tabel 1. Lanjutan

\begin{tabular}{|c|c|c|c|c|c|c|c|c|}
\hline \multirow{2}{*}{ No. } & \multirow{2}{*}{$\begin{array}{l}\text { Satuan } \\
\text { lahan }\end{array}$} & \multirow{2}{*}{$\begin{array}{c}\text { Toksisitas(xc) } \\
\text { Salinitas }\end{array}$} & \multirow{2}{*}{$\begin{array}{c}\text { Sodisitas (xn) } \\
\text { Alkalinitas/ESP }\end{array}$} & \multirow{2}{*}{$\begin{array}{c}\text { Bahaya } \\
\text { erosi (eh) } \\
\text { Lereng }\end{array}$} & \multirow{2}{*}{$\begin{array}{c}\begin{array}{c}\text { Bahaya } \\
\text { banjir (fh) }\end{array} \\
\text { Banjir }\end{array}$} & \multicolumn{2}{|c|}{ Penyiapan lahan (lp) } & \multirow{2}{*}{$\begin{array}{l}\text { Kesesuaian } \\
\text { lahan aktual }\end{array}$} \\
\hline & & & & & & $\begin{array}{c}\text { Batuan } \\
\text { permukaan }\end{array}$ & $\begin{array}{c}\text { Singkapan } \\
\text { Batuan }\end{array}$ & \\
\hline 1 & $\begin{array}{l}\text { III, D1, } \\
\text { Blk, Lit }\end{array}$ & $0,55 / \mathrm{S} 1$ & $1,83 / \mathrm{S} 1$ & $>15-25 / \mathrm{s} 3$ & $\mathrm{~F} 0 / \mathrm{S} 1$ & $5 / \mathrm{S} 2$ & $4 / \mathrm{S} 2$ & S3e \\
\hline 2 & $\begin{array}{l}\text { IV, D1, } \\
\text { Tgl, Lit }\end{array}$ & $0,51 / \mathrm{S} 1$ & $1,29 / \mathrm{S} 1$ & $>25-45 / \mathrm{S} 3$ & $\mathrm{~F} 0 / \mathrm{S} 1$ & $4 / \mathrm{S} 1$ & $5 / \mathrm{S} 1$ & S3ne \\
\hline 3 & $\begin{array}{l}\text { I, K4 } \\
\text {,Swh, Alv }\end{array}$ & $1,8 / \mathrm{S} 1$ & $2,58 / \mathrm{S} 1$ & $<8 / \mathrm{S} 1$ & $\mathrm{~F} 0 / \mathrm{S} 1$ & $3 / \mathrm{S} 1$ & $2 / \mathrm{S} 1$ & S3n \\
\hline 4 & $\begin{array}{l}\text { II, K4, } \\
\text { Tgl, Mdt }\end{array}$ & $1,79 / \mathrm{S} 1$ & $2,27 / \mathrm{S} 1$ & $>8-15 / \mathrm{S} 1$ & $\mathrm{~F} 0 / \mathrm{S} 1$ & $10 / \mathrm{S} 2$ & $6 / \mathrm{S} 2$ & S3n \\
\hline 5 & $\begin{array}{l}\text { V, K4, } \\
\text { Tgl, Mdt }\end{array}$ & $1,99 / \mathrm{s} 1$ & $2,31 / \mathrm{S} 1$ & $>45 / \mathrm{N}$ & $\mathrm{F} 0 / \mathrm{S} 1$ & $12 / \mathrm{S} 2$ & $7 / \mathrm{S} 2$ & $\mathrm{Ne}$ \\
\hline 6 & $\begin{array}{l}\text { III, D2, } \\
\text { Swh, Alv }\end{array}$ & $2,39 / \mathrm{S} 2$ & $2,44 / \mathrm{S} 1$ & $>15-25 / \mathrm{S} 3$ & $\mathrm{~F} 0 / \mathrm{s} 1$ & $4 / \mathrm{S} 1$ & $2 / \mathrm{S} 1$ & S3ne \\
\hline 7 & $\begin{array}{l}\text { I,D2, Tgl, } \\
\text { Lat }\end{array}$ & $0,29 / \mathrm{S} 1$ & $1,35 / \mathrm{S} 1$ & $<8 / \mathrm{S} 1$ & $\mathrm{~F} 0 / \mathrm{s} 1$ & $3 / \mathrm{S} 1$ & $2 / \mathrm{S} 1$ & S2wn \\
\hline 8 & $\begin{array}{l}\text { III, D2, } \\
\text { Tgl, Lat }\end{array}$ & $0,39 / \mathrm{S} 1$ & $1,16 / \mathrm{S} 1$ & $>15-25 / \mathrm{S} 3$ & $\mathrm{~F} 0 / \mathrm{s} 1$ & $4 / \mathrm{S} 1$ & $6 / \mathrm{s} 1$ & S3e \\
\hline 9 & $\begin{array}{l}\text { II, D1, } \\
\text { Blk, Lit }\end{array}$ & $0,37 / \mathrm{S} 1$ & $1,50 / \mathrm{S} 1$ & $>8-15 / \mathrm{S} 2$ & $\mathrm{~F} 0 / \mathrm{S} 1$ & $2 / \mathrm{S} 1$ & $4 / \mathrm{S} 1$ & S3n \\
\hline
\end{tabular}

Sumber : Sumber : Hasil analisis pengukuran lapang, laboratorium kimia dan kesuburan tanah UNHAS, dan hasil olah data dari BBWS. 


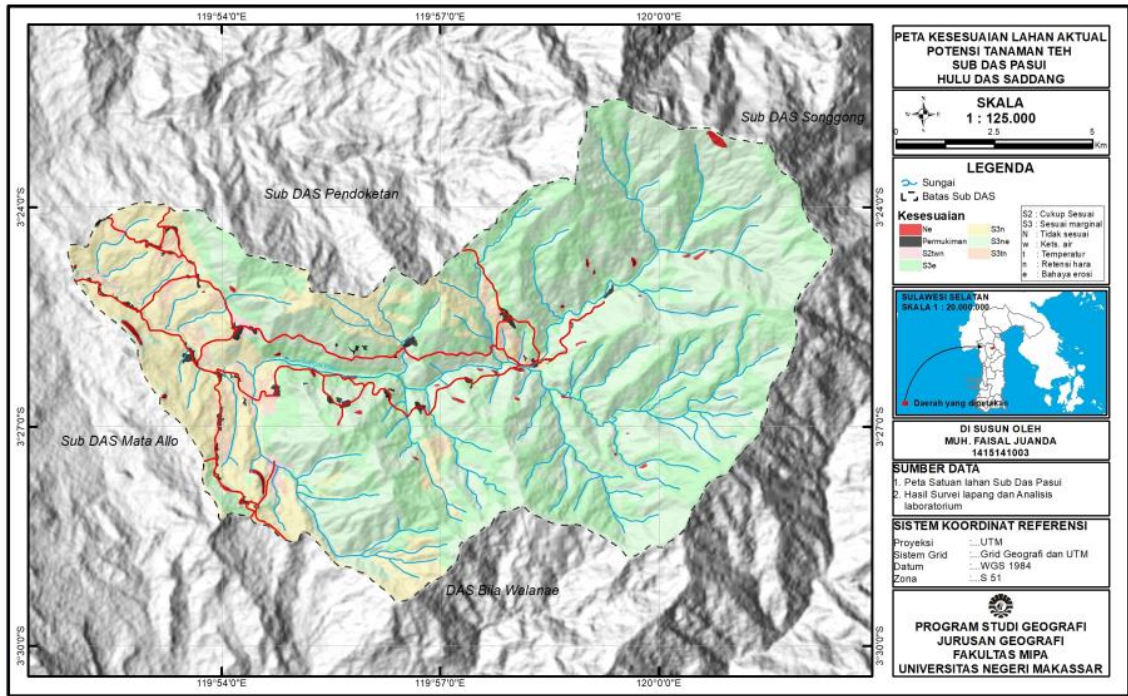

Gambar 4 Peta kesesuaian lahan aktual untuk potensi budidaya tanaman teh

Peta kesesuaian lahan aktual untuk potensi budidaya tanaman teh kemudian dianalisis untuk memperoleh luas sub DAS Pasui berdasarkan potensi kesesuaian lahan untuk tanaman teh seperti pada tabel 2 berikut.

Tabel 2 Luas Sub DAS Pasui Berdasarkan Kesesuaian Lahan Aktual Potensi Tanaman Teh

\begin{tabular}{|c|c|c|c|}
\hline No. & $\begin{array}{l}\text { Potensi Kesesuaian lahan untuk } \\
\text { tanaman teh }\end{array}$ & Nomor Satuan lahan & Luas (ha) \\
\hline 1 & $\mathrm{Ne}$ & $54,55,56,57,58$ & 61,85 \\
\hline 2 & S2wn & $2,3,13,14,18$ & 70,91 \\
\hline 3 & $\mathrm{~S} 3 \mathrm{e}$ & $25,26,27,28,30,31,33,35,38,45,46,48$ & 4779,38 \\
\hline 4 & S3n & $\begin{array}{c}1,4,5,6,7,8,9,10,11,12,15,17,19,20 \\
21,22,23,24,34,36,39\end{array}$ & 2807,03 \\
\hline \multirow[t]{2}{*}{5} & S3ne & $29,32,37,43,44,47,49,50,51,52,53$ & 5769,73 \\
\hline & & Luas & 13508.90 \\
\hline
\end{tabular}

Sumber: Peta Potensi Kesesuaian lahan untuk tanaman teh Sub DAS Pasui

Berdasarkan hasil pencocokan karakteristik lahan Sub DAS Pasui dan kriteria syarat tumbuh tanaman teh (Camellia Sinensis L. Kuntze), maka faktor pembatas dominan untuk potensi penanamannya adalah suhu, retensi hara dan bahaya erosi.

\section{PEMBAHASAN}

Rerata suhu udara pada lokasi penelitian termasuk suhu iklim sedang. Temperatur pada lokasi penelitian berpotensi sangat sesuai (S1) hingga cukup sesuai (S2). Adapun menurut Dalimonthe (2016) tanaman teh akan berhenti tumbuh pada suhu dibawah $13^{\circ} \mathrm{C}$ atau diatas $30^{\circ} \mathrm{C}$. Berdasarkan pendapat tersebut maka suhu di Sub DAS Pasui berpotensi untuk penanaman teh.

Rerata curah termasuk menegah. Ketersediaan air tersebut berpotensi cukup sesuai (S2). Pada daerah pegunungan karena awan yang membawa air akan naik terus ke atas dan akan terakumulasi sebelum mencapai puncak gunung. Akumulasi awan ini akan menghasilkan hujan orografis yang membawa banyak air hasil akumulasi (Novita, 2011).

Tingkat drainase lokasi titik sampel penelitian tegolong baik dan berpotensi ditumbuhi teh. Hal ini karena Topografi yang berlereng - lereng dan tidak ditemukannya genangan dan rawa - rawa. Kondisi tanah yang memiliki drainase baik seperti ini berpotensi mendukung pertumbuhan akar secara optimal (Effendi, 2011).

Tektur halus dan agak halus diperoleh pada lokasi penelitian disebebkan karena fraksi tanah didominasi oleh liat dan lempung. Tekstur pada lokasi penelitian terdiri atas kelas tekstur agak halus pada titik sampel 1, 2, 5, 6, 8 dan 9. Sedangkan kelas tektur halus terdapat pada titik sampel 3, 4, dan 7. Kelas tekstur halus dan agak halus berpotensi sangat sesuai (S1). Menurut Hardjowigono (2010) pada tekstur halus akan dapat menahan unsur 
- unsur yang diperlukan tanaman dan memiliki bahan organik lebih banyak. Kemampuan menahan air juga lebih besar dan fraksi liat dapat meningkatkan kemampuan dalam pertukaran kation-kation.

Fraksi kasar lokasi penelitian termasuk kelompok sedang. Potensi kelas sangat sesuai (S1) terdapat pada titik sampel 3, 5, 7, dan 8 dengan persentase bahan kasar berkisar antara $1-10 \%$. Sedangkan berpotensi cukup sesuai (S2) terdapat titik sampel 1, 2, 4, 6 dan 9 dengan persentase bahan kasar berkisar $15-35 \%$. Fraksi kasar pada lokasi penelitian sedemikian rupa karena pada horizon tanah di lokasi pengambilan sampel terbentuk belum sepenuhnya melapuk khususnya material sebesar $>2 \mathrm{~mm}$. Kondisi tanah dengan bahan kasar banyak mengakibatkan air mudah lolos dan hanya sedikit yang dapat diserap tumbuhan. Akan tetapi sebaliknya jika sedikit maka air akan lebih mudah disimpan dan ditahan dan jika berlebihan maka dapat menimbulkan genangan (Hardjowigeno, 2010)

Kedalaman efektif tanah pada lokasi penelitian untuk tanaman termasuk dalam. Kedalaman efektif lokasi penelitian berkisar antara $105 \mathrm{~cm}-210 \mathrm{~cm}$. berdasarkan syarat tumbuh tanaman teh, kedalaman seperti diatas berpotensi sangat sesuai (S1). Jenis bahan induk yang mendominasi lokasi penelitian adalah sedimen dan malihan. Regolithnya dapat mencapai $100 \mathrm{~cm}$ sampai $200 \mathrm{~cm}$ sedangkan batuan beku terobosan regolithnya lebih dangkal < $100 \mathrm{~cm}$ (Siswanto, 2006). Bahan Induk dari vulkanik yang ketika melapuk dapat mengakibatkan kedalam efektif dapat mencapai 1 sampai dengan 3 meter (Wardhana, 2013). Hal ini cukup berpotensi untuk tanaman teh karena pada umumnya tanaman ini memiliki akar tunggang yang membutuhkan tanah dalam untuk pergerakan dan penyebaran akar menyerap zat hara tanah.

KTK liat lokasi penelitian termasuk tinggi. Nilai KTK liat pada semua titik pengambilan sampel memiliki potensi sangat sesuai (S1). Nilai KTK liat berbanding lurus dengan tekstur liat. Sub DAS Pasui didominasi tekstur liat dan lempung berliat yang menyebabkan nilai KTK liat juga tinggi ditumbuhi teh. Nilai KTK liat yang tinggi berpotensi bagi teh untuk lebih kuat menyerap koloid-koloid dan memperturkarkan kation-kation (Hakim, 1986).

Kejenuhan basa yang diperoleh dari uji sampel dari lokasi penelitian masuk dalam klasifikasi kurang subur. Kejenuhan basa pada lokasi penelitian digolongkan menjadi dua kelas potensi kesesuaian yaitu cukup sesuai dan sesuai marginal. Kelas kesesuaian cukup sesuai (S2) berpotensi pada titik sampel 1, 2, 7, 8 dan 9 dengan nilai Kejenuhan basa 22,5 - 32,2\%. Sedangkan kelas kesesuaian sesuai marginal (S3) berpotensi pada titik sampel 3, 4, 5 dan 6 dengan nilai Kejenuhan basa $43-57,5 \%$. Lokasi penelitian sebagian merupakan daerah karst (kapur) dengan jenis tanah mediteran. Zat kapur pada umumnya bersifat agak basa sehingga sifat tanah tidak sesuai yang dikehendaki tanaman teh.

Keadaan tanah Sub DAS pasui berdasarkan kategori derajat keasaman termasuk agak masam sampai netral. Hal ini dikarenakan pada lokasi terdiri dari sebagian daerah vulkanik yang bersifat agak masam sampai netral dan sebagian daerah karst yang bersifat cenderung netral sampai agak basa. Kelas kesesuaian cukup sesuai (S2) berpotensi pada titik sampel 1, 7 dan 8 dengan nilai pH antara 5,5-5,75. Sedangkan pada kelas sesuai marginal (S3) berpotensi pada titik 2, 3, 4, 5, 6 dan 9 dengan nilai $\mathrm{pH}$ antara $6-7$. Pada daerah yang tanahnya sebagian vulkanik masih berpotensi tumbuhnya teh kerena teh menghendaki tanah sedikit masam, sedangkan tanah pada daerah karst membutuhkan penangan agar lebih potensial untuk ditanami teh karena bersifat netral sampai sedikit basa.

Kadar C - Organik Pada lokasi penelitian termasuk rendah sampai sedang. Keseluruhan titik sampel berpotensi sangat sesuai (S1) untuk ditumbuhi teh. Pengaruh ketersediaannya C - Organik adalah daya tanah untuk menahan air tinggi sehingga mengurangi erosi serta penyangga zat hara. Selain itu C - Organik memperbaiki sifat fisis tanah agar sehingga membantu perkembangan perakaran teh (Sukmati, 2015).

Kategori salinitas lokasi penelitian secara umum termasuk terpengaruh rendah. Salinitas tanah pada lokasi penelitian tergolong dalam kelas kesesuaian (S1). Hal ini ditandai dengan minimnya ditemukan kerak - kerak putih pada permukaan tanah serta tidak ada cekaman air pada pengambilan sampel. Tingkat Salinitas tersebut tidak terlalu bepengaruh sebagai pembatas potensi tanaman teh. Selain itu, keracunan tanaman akan ion natrium dan klorida juga terminimalisir dengan rendahnya tingkat salinitas (Djukri,2009).

Alkalinitas/ESP pada lokasi penelitian berpotensi sangat sesuai (S1). Pada lokasi penelitian tidak ditemukan residu berbentuk tepung berwarna gelap pada permukaan tanah dan drainase baik tanpa ada genangan sehingga tingkat alkalinitas pada lokasi penelitian termasuk tanah non sodik. Keadaan tanah normal atau non sodik tidak terlalu menjadi pembatas potensi tumbuhnya tanaman teh. Normalnya alkalitias/ESP tanah lokasi penelitian berpotensi untuk pertumbuhan akar tanaman teh dan minimalisir perkembangan mikroba. Kondisi 
normal tersebut juga memungkinkan tidak ada penyumbatan pori tanah sebagai jalan masuk air dan oksigen serta tidak ada pelumpuran pada lahan (Foth, 1994).

Bahaya erosi mengacu pada kelerengan. Pada titik lokasi terdiri dari kelas lereng landai yang terdapat pada titik sampel 3, 4, dan 9. Kelas agak curam terdapat pada kelas 1, 6, dan 8. Kelas curam terdapat pada titik 2. Kelas sangat curam terdapat pada titik 5. Pada umumnya tanaman teh menghendaki lahan yang berlereng lereng sehingga tidak ada genangan pada media tanah tumbuhnya.

Bahaya banjir merupakan gabungan antara lama periode banjir dan kedalaman saat banjir. Berdasarkan hasil survey tidak ada bahaya banjir dalam setahun pada tiap titik sampel yang diamati. Hal berpotensi sangat sesuai (S1) untuk mendukung tanaman teh tumbuh dengan baik tanpa ada genangan pada lahan penanamannya dan pada saat pertumbuhan dan perkembangannya.

Batuan permukaan dan singkapan batuan pada lokasi termasuk kategori sedang. Batuan permukaan di lokasi penelitian terdiri dari dua kelas potensi yaitu kelas cukup sesuai (S2) pada titik 1, 4 dan 5 dengan persentase batuan permukaan $5-12 \%$. Sedangkan kelas sangat sesuai (S1) terdapat pada titik sampel 2, 3, 6, 7, 8 dan 9. Singkapan batuan pada lokasi penelitian juga terdiri dari dua kelas potensi kesesuaian yaitu kelas sangat sesuai (S1) dan kelas cukup sesuai (S2). Kelas sangat sesuai (S1) terdapat pada titik sampel 2, 3, 6, 7, 8 dan 9. Sedangkan kelas cukup sesuai terdapat pada titik 1, 4, dan 5. Pada lokasi didominasi oleh topografi berlereng lereng sehingga batuan permukaan sebagian telah tergelinding ke dasar lereng bawah. Batuan - batuan singkapan yang terdapat pada horizon tanah merupakan sisa pelapukan belum lapuk. kondisi seperti ini memungkinkan akar teh berpotensi menembus horizon tanah tidak terlalu sukar dan lebih mudah memperoleh zat hara. Berdasarkan uraian di atas, faktor pembatas terberat pada kesesuaian lahan aktual potensi tanaman teh adalah suhu, retensi hara, dan bahaya erosi.

\section{KESIMPULAN}

Kesesuaian lahan aktual untuk potensi budidaya tanaman teh (Camellia Sinesis. L.Kuntze) di Sub DAS Pasui terdiri dari kelas cukup (S2) seluas 70,91 Ha, Kelas Sesuai Marginal (S3) 13376.14 Ha dan kelas tidak Sesuai (N) seluas 61,85 Ha dengan faktor pembatas dominan adalah suhu, retensi hara dan bahaya erosi.

\section{DAFTAR PUSTAKA}

Djukri. 2009, Cekaman Salinitas terhadap Pertumbuhan Tanaman, Prosiding Seminar Nasional Penelitian, Pendidikan dan Penerapan MIPA, Fakultas MIPA, Universitas Negeri Yogyakarta, 16 Mei 2009.

Foth H. D.1994. Dasar - Dasar Ilmu Tanah. Terjemahan Soenartono Adi Soemarto. Edisi keenam. Erlangga. Jakarta.

Hakim, 1986. Dasar-dasar Ilmu Tanah. Universitas Lampung. Lampung.

Hardjowigeno, S. 2010. Ilmu Tanah. Jakarta : Akademika Pressindo.

Novita, Sisilia, 2011. Asal Mula Hujan. Sidoarjo: Pumpkids (Kelompok Masmedia Buana Pustaka).

Siswanto. 2006. Evaluasi Sumber Daya Lahan. Surabaya : UPN Press.

Sugiyono, 2008. Metode Penelitian Kunatitatif Kualitatif dan R\&D. Bandung : Alfabeta.

Sukmawati. 2015. Analisis Ketersediaan C-Organik Di Lahan Kering Setelah Diterapkan Berbagai Model Sistem Pertanian Hedgerow. Fakultas Pertanian, Peternakan dan Perikanan. Universitas Muhammadiyah Pare - Pare.

Sukmono, A. 2015. Analisa Kesesuaian Lahan Teh Di Banjarnegara Menggunakan Teknologi Penginderaan Jauh Dan Sistem Informasi Geografis. Program Studi Teknik Geodesi, Fakultas Teknik Universitas Diponegoro: Jurnal GEOID Vol. 10 No. 2:179.

Tea Association of Canada. 2012. 5th Symposium on Tea \& Human Health .Toronto. Kanada. 